\title{
Economic and Institutional Determinants of Mergers \& Acquisitions in BRICS, G7 and G20 Economies
}

\author{
Keshab Bhattarai \\ University of Hull
}

\author{
Asha Prasuna \\ Somaiya Vidyavihar University \\ S. N. V. Siva Kumar \\ Somaiya Vidyavihar University
}

Factors contributing towards increasing the number of mergers and acquisitions ( $M \& A)$ among firms and the volume of business and sales of these firms are assessed empirically based on results of the static and dynamic panel data models for BRICS, G7 and G20 countries in this investigation. While the higher rates of economic growth and foreign direct investment (FDI) contribute positively to the occurrence of $M \& A$ activities, these effects are even more prominent with greater efficiency in government institution, qualities of regulation, voice accountability and control of corruption. In the meantime, higher inflation and corporation tax rates reduce the numbers but the volumes of the $M \& A$ activities. Size of the business matters, medium or large corporations merge to exploit scale economies, to benefit from larger markets and to retain market power by operating across the globe.

Keywords: mergers acquisitions, government policy and regulation, international investment, comparative studies of countries, panel data models

\section{INTRODUCTION}

In the last 30 years, mergers and acquisitions (M\&A) activities have evolved as a part of inorganic growth strategy of corporate firms, and are maturing in the international scenarios. While in India, the regulatory environment was not conducive to mergers and acquisition activities during 1970's and up to 1990's policy reforms moved fast after the financial reforms initiated in 1990s with the replacement of the MRTP Act by the Competition Act, 2002. Then the 2008 crisis had a deep impact on the economy which manifests itself in several structural changes in the economy, like change in interest rates, market size, banking and liquidity and policies on tax and trade. These reforms had opened opportunities both for domestic and multi-national firms to use $M \& A$ as a corporate strategy to achieve various synergies to enhance financial, strategic fit, geographical reach, technology, macroeconomic and conducive business environment. 
In the corporate field, top management envisages M\&A as a critical activity for its rapid growth with several benefits to both target and acquiring companies. Such type of inorganic mode of growth is increasingly becoming a central part of strategy for organizations in developing markets while keeping the global market to its focal strategy point. However, the success rates of the deals have not significantly increased in developed markets, and developing markets still struggle to make M\&A successful.

Normally a typical M\&A transaction takes place with a good analysis of financial, legal and technology factors. The pre and post deal values of financial factors like Market Capitalization, Deal Size, Enterprise Value, EBITDA, P/E Ratio, and Market to Book, Free Cash Flows, Financial Leverage, Liquidity, Sales Growth, and Market Price per Share are used to compare the performance of the transactions or the M\&A deal. Empirical research in M\&A field evolved around quantitative, qualitative and survey-based techniques. There have been many studies which identified the issues and challenges in the M\&A process. Most of the data and information are captured by various data service providing entities, and their performance has been analyzed and measured accordingly. Success and failures can be partially captured predominantly looking at the pre and post-merger valuation of the firm and the stock price while analyzing the number of cross-border deals and by the behavior of the acquired firms. Global research has also been aimed at capturing reasons of success or failure of M\&A that can be attributable to valuation, regulations or financial impacts.

The paper particularly explores the following questions:

i. Are there significant relationships between economic factors and mergers and acquisitions?

ii. Are there significant relationships between institutional factors and mergers and acquisitions?

This study assesses three economic factors namely, inflows and outflows of Foreign Direct Investment, Gross Domestic Product (GDP), inflation and corporate tax rates. Then we investigate influence of six institutional factors including the government effectiveness, control of corruption, political stability, and rule of law, regulatory quality and voice accountability. The sample consists of the time series data on above variables from G7, G20 and BRICS countries for the period of 2000 to 2020 . The data are sourced from OECD and World Bank websites, World-wide Governance Indicators, 2020 and the number and volumes of mergers from the Institute of the M\&A.

The study used fixed and random effect as well as quantile panel data models for estimation of coefficients on determining factors of the numbers and volumes of the M\&A in this relationship. The paper concludes that both economic and institutional factors are significant in determining the performance of M\&A deals.

\section{REVIEW OF THE LITERATURE ON M\&A}

It can be observed that most of the literature in M\&A domain focuses on assessing the post-merger success or failures. Theoretical framework on cross-border capital flows and deals draws on the literature related to the determinants of outbound foreign direct investment (OFDI). While initial theories tried to formulate ideas in the context of developed economies, later modifications were made to suit to the developing and emerging economies. A short review of relevant literature is done in this section to put our study in the proper context.

Initial theoretical perspectives are found in Leibenstein (1966)model on allocative efficiency vs. "XEfficiency" in explaining advantages of mergers. Farrell, \& Shapiro (1990) shows impacts of horizontal merger in equilibrium; Jensen (1986) dealt with Agency Costs of Free Cash Flow, Corporate Finance, and Takeovers; Shleifer and Vishny (2003) show Stock market driven acquisitions. Andrade, Mitchell and Stafford(2001) found new evidence and perspectives on mergers. Harford(2005) explains as towhat drives merger waves. Hazelkorn, Zennerand Shivdasani (2004) discussed about creating value with mergers and acquisitions. A comprehensive analysis for motives of merger are covered in Tirole and Jean (1988).

More updates on recently available databases are found in recent studies by Orefice, Slyand Toubal (2021) who show impacts of cross-border merger and acquisition activity on wage dynamics. Carril-Caccia and Pavlova(2020) illustrate impacts of Mergers and acquisitions \& trade fora global value chain analysis.

Journal of Applied Business and Economics Vol. 23(7) 2021 
Leepsa and Mishra(2013) dealt with the timeline for M\&A payoffs using an empirical study in Indian context. Eaton, Liu and Officer(2019) focused on rethinking of measures of M\&A Deal Premiums.

Many studies focus on financial perspectives. Travlos (1987) take on corporate takeover bids, methods of payment, and bidding firms' stock returns, Beitel, Schiereck, and Wahrenburg (2004) explain M\&A success in European banks, Hirshleifer (1995) discuss strategic and informational issue relating to finance, Kyriazis (2010) dealt with long-term post acquisition performance of Greek acquiring firms, Ouyang and Hilsenrath (2017) studied M\&A and capital expenditure in healthcare based on stock price variation; Sehgal, Delistingee and Deisting (2012) assess the impacts of M\&A announcement and financing strategy on stock returns taking evidence from BRICS markets, Vazirani (2012) provides a literature review for mergers and acquisitions performance evaluation; Weaver, Harris, Bielinski and MacKenzie (1991) assess the financial management aspects of merger and acquisition valuation.

Managerial and business perspectives are presented in other studies. Kim(2010)studied how elections play behind making or breaking deals on mergers \& acquisitions. Roll (1986) studied the Hubris Hypothesis of Corporate Takeovers; Cirjevskis (2015) provides empirical assessment of competence-based synergy in acquisition process. Ghosh, and Leverage (2008) assess firm-level evidence for India from foreign borrowing and corporate performance. King, Dalton, Daily and Covin (2004) show meta-analyses of postacquisition performance indications unidentified moderators; Xia, Tan and Tan(2008) illustrate entry and bandwagon effect due to the rise and decline of international equity joint venture in China.

Dunning (1980), in his paper used three parameters of Ownership, Location and Internalization advantages to the internalization theory to explain the international business activities. Golbe and White (1988) developed hypothesis to test the impact of underlying fundamental economic factors on patterns of mergers and acquisitions using time-series regression analysis on post-World War II merger data. Mitchell and Mulherin (1996) analyzed industry-level patterns in takeover and restructuring activity during the 19821989 period, across 51 industries in USA. Aliberti (1998) examined the spatial implication of Canadian domestic as well as international mergers and acquisition activity.

Floyd (2003) studied the impact of cross-border acquisitions versus Greenfield Foreign Direct Investments (FDI) on Polish economy. Giovanni (2005) analysed the role of macroeconomic and financial variables in the foreign direct investment (FDI) decision of firms by building various econometric specifications around the 'gravity model' on a large panel data of cross-border Merger \& Acquisition (M\&A) deals during the period 1990 - 1999. Epstein (2005) delved into the dominants that make a merger successful and how to evaluate a merger success.

Martynova, Oosting and Renneboog (2006) investigated the long-term profitability of corporate takeovers of which both the acquiring and target companies are from continental Europe and the UK. Nigh and Boschetti (2006) probed into the forces that influence M\&A decision making, such as satisfying various stakeholders, attaining economies of scale, getting access to capital. Moeller, et al (2012) provided a proprietary methodology to measure a country's M\&A maturity. The study computes a theoretical maturity index for M\&A purposes (MARC M\&A maturity index) using 36 factors in total, which captures key legal, economic, financial, political, technological, and socio-cultural characteristics from a total of 175 countries based on information available at the end of 2009. The index classifies different maturity stages of development in M\&A activity, i.e., mature, transitional, and emerging markets. The tests show that the socio-cultural environment acts as a determinant of M\&A activity within the mature markets group, whereas the economic, financial, political, and technological environments determine differences in M\&A activity amongst countries in the transitional development stage.

Boateng, Hua, Uddin and Du (2014) concluded an empirical study and investigated whether shocks to home country macroeconomic factors are transmitted to cross-border mergers and acquisitions at significant levels. Home country economic conditions significantly influence the outward cross border M\&As, as it is an indication of prosperity of the economy. Bhargavi et al (2016) examined locational determinants of outward foreign direct investment of Indian pharmaceutical companies. The study considered variables to measure cross-country characteristics for 33 countries for the period 2000-2013 using panel data approach. The study concluded that strategic assets like patents/trademark filing, R\&D expenditure of host countries as a key- determinants influencing the Indian M\&A pharmaceutical deals. 
From above review of the existing works we tend to believe that there has been no study on M\&A issues comparing BRICS, G7 and G20 economies. Our paper aims to fill this gap in the relevant M\&A literature.

\section{PANEL DATA MODEL OF MERGER \& ACQUISITIONS}

Motivations and modalities of merger vary across countries. Good economic environment at home and the strong institutions are important for prosperity of business. Healthy companies merge if that contributes to the profit, revenue or sales maximization or for strategic reasons. Mergers are quick if the qualities of institutions are good including effective law and order and transparency in business. Control of corruption and voice accountability also create favorable environment for merger and acquisitions. Mergers may raise the market or markup power of participating firms.

M\&A decision basically occurs at the firm level across industries. Macroeconomic factors and institutional factors influence on such decisions. For this reason, our empirical analysis focuses on economic and institutional variables across time and for three groups namely BIRICS, G7 and G20 countries. In our best knowledge this is first study on this issue for comparison across these three categories of advanced and emerging economies controlling over 80 percent of global GDP and M\&A activities.

We first construct a generic panel data model in which number of sales or purchase mergers respond to the economic and institutional variables. Number of mergers $\left(N_{i t}\right)$ for country $i$ at time $t$ depends on economic variables including the growth rate (GR), inflation (infl), FDI inflows (FDI), and FDI outflows (FDO), and corporate tax (CT) and institutional variables including government effectiveness (GE), control of corruption (CC), political stability (PS), Rule of Law (RL), regulatory quality (RQ), and voice accountability (VA).

$N_{i t}=\alpha_{i}+\beta^{X} X_{i, t}^{F}+\beta^{I} I N S_{i, t}^{I}+\mu_{\mathrm{i}}\left(\mathrm{X}_{\mathrm{it}} \times \mathrm{INS}_{\mathrm{it}}\right)+\lambda_{t}+e_{i t}$

In greater details this means

$\mathrm{N}_{\mathrm{it}}=\beta_{0}+\beta_{1} \mathrm{GR}_{\mathrm{it}}+\beta_{2} \mathrm{Inf}_{\mathrm{it}}+\beta_{3} \mathrm{FDI}_{\mathrm{it}}+\beta_{4} \mathrm{FDO}_{\mathrm{it}}+\beta_{5} \mathrm{CT}_{\mathrm{it}}+\beta_{6} \mathrm{GE}_{\mathrm{it}}+\beta_{7} \mathrm{CC}_{\mathrm{it}}+\beta_{8} \mathrm{PS}_{\mathrm{it}}+\beta_{9} \mathrm{RL}_{\mathrm{it}}$ $+\beta_{10} \mathrm{RQ}_{\mathrm{it}}+\beta_{11} \mathrm{VA}_{\mathrm{it}}+\mu_{\mathrm{i}}\left(\mathrm{X}_{\mathrm{it}} \times \mathrm{INS}_{\mathrm{it}}\right)+\lambda_{t}+e_{i t}$

In theory while determining the numbers or volume of mergers, we expect coefficients on growth and FDIto be positive and coefficients $\beta_{2}$ and $\beta_{4}$ on inflation and FDI outflows to be negative. Then we also expect coefficients of institutional variables are expected to have positive impacts, thus $\beta_{6}$ to $\beta_{11}$ to be positive. The interaction variables can be positive or negative depending on the nature of interactions. The effect of time is measured by $\lambda_{t}$. We consider static and dynamic panel data models to assess the influence of these variables on number of mergers.

\section{DATA SOURCES AND EMPIRICAL ANALYSIS}

The data on economic variables for BRICS, G7 and G20 countries were collected from OECD database for the period of 20 years from 2000 to 2020 for all three Groups; data on M\&A were from the Institute of Merger and Acquisition (https://imaa-institute.org/mergers-and-acquisitions-statistics/) and UNCTAD cross-border M\&A database (www.unctad.org/fdistatistics). Data on institutional variables were taken from WGI dataset of the World-wide Governance Indicator, 2020.

Fixed and random effect panel data models were estimated by taking number of mergers and acquisitions deals and value as dependent variable for all three groups of countries on above economic and institutional variables and results are tabulated in Tables 1 to Table 6. Two panel quintile regression models for G20 countries were also estimated and results are presented in Table 7. Independent variables used in all models include five economic variables namely, growth rate of gross domestic product (GDP), Inflation, 
Foreign Direct Investment Inflows (FDIIN), Foreign Direct Investment Outflows (FDIOUT), corporate tax and six Institutional governance variables namely, government effectiveness (GE), control of corruption (CC), political stability (PS), Rule of Law (RL), regulatory quality (RQ), and voice accountability (VA).

As for the number of M\&A purchases for BRICS countries data are concerned, it can be observed from Table 1 that, fixed effects Model 1, where only economic variables are taken into equation, coefficient onFDIIN is significant at $1 \%$ level along with that on the constant term. Coefficients on all other economic variables turned out to be insignificant. This model has an R-square value of 0.44 . We move on to random effect estimation on Model 2. Only the coefficient on the FDIIN is significant at 1\% level in the RE1 model in column (2) estimated coefficients in all other economic independent variables turned out not to be statistically significant.

Now we introduce additional institutional variable for Model FE2 in column (3), where both economic and institutional governance variables are used as independent variables. It can be observed that coefficient on FDIIN is significant at $1 \%$, and government effectiveness (GE) is significant at $5 \%$ level. This model has an R-square value of 0.48. Our best result is Model 4, RE2 as presented in column (4)which had all economic and institutional variables as independent variables as in model (3) but now coefficient on five variables namely, GDP, FDIIN, GE, PS1, and VA are turned out to be significant at 1\%, while RQ is significant at $10 \%$ and Inflation was significant at $5 \%$ level of significance. Thus we can infer that numbers of mergers are positively linked to the rate of economic growth, inflows and outflows of FDI, effectiveness of the government, and voice accountability. Political instability, poor qualities of rules of laws and quality of regulation had harmful effects on number of M\&A deals among BRICS countries.

TABLE 1

NUMBER OF PURCHASE MERGERS IN BRICKS COUNTRIES: PANEL DATA MODEL

\begin{tabular}{lllll}
\hline & $(1)$ & $(2)$ & $(3)$ & $(4)$ \\
VARIABLES & Model FE1 & Model RE1 & Model FE2 & Model RE2 \\
\hline GDP & 3.192 & 2.365 & 2.030 & $14.14^{* * *}$ \\
Inflation & $(3.709)$ & $(3.771)$ & $(3.454)$ & $(4.351)$ \\
& 2.752 & 1.937 & 2.281 & $-8.349^{* *}$ \\
FDIIN & $(3.368)$ & $(3.425)$ & $(3.140)$ & $(3.892)$ \\
& $0.00192^{* * *}$ & $0.00202^{* * *}$ & $0.00162^{* * *}$ & $0.00298^{* * *}$ \\
FDIOUT & $(0.000219)$ & $(0.000221)$ & $(0.000222)$ & $(0.000193)$ \\
& $2.56 \mathrm{e}-05$ & $2.73 \mathrm{e}-05$ & $1.75 \mathrm{e}-05$ & $6.51 \mathrm{e}-05$ \\
GE & $(3.74 \mathrm{e}-05)$ & $(3.85 \mathrm{e}-05)$ & $(3.37 \mathrm{e}-05)$ & $(4.81 \mathrm{e}-05)$ \\
& & & $7.369^{* *}$ & $10.16^{* * *}$ \\
CC & & $(3.086)$ & $(2.424)$ \\
& & & 3.730 & 0.411 \\
PS1 & & $(2.282)$ & $(2.387)$ \\
& & -0.152 & $-4.452^{* * *}$ \\
RL & & $(1.366)$ & $(1.376)$ \\
RQ & & -4.028 & -0.502 \\
& & & $(2.834)$ & $(3.448)$ \\
VA & & -3.428 & $-4.673^{*}$ \\
Constant & & $(2.435)$ & $(2.804)$ \\
& & & -0.110 & $7.685^{* * *}$ \\
Observations & 112 & & $(2.417)$ & $(0.944)$ \\
R-squared & 0.444 & -125.3 & $-572.4 * * *$ \\
Number of ID & 7 & $(70.17$ & $(184.7)$ & $(81.44)$ \\
Stand & & & \\
\end{tabular}

Standard errors in parentheses ${ }^{* * *} \mathrm{p}<0.01,{ }^{* *} \mathrm{p}<0.05,{ }^{*} \mathrm{p}<0.1$ 
Next we take volume of sale mergers and acquisitions as dependent variable and regress it on economic and institutional governance variables as independent variables for these BRICKS economies. Estimates of coefficients of the four panel regression models corresponding to those above are presented in Table 2. The estimated results reveal that in Model 1, FE1, where the economic variables are included as independent variables, only coefficients on FDIIN and the constant term turned out to be positive and significant at $1 \%$ level of significance. This equation has R square value of 0.486. Only FDIIN turned out to be positive and significant at $1 \%$ level of significance in the random effect model in Column (2). In model 3, FE2, coefficients on FDIIN and RQ were positive and significant at $1 \%$ level, while the coefficient on government effectiveness was significant at 5\% level.

Model 4, RE2 revealed that FDIIN, PS1, VA and constant are significant at 1\%, GDP and RQ are significant at 5\% and CC coefficient is significant at 10\%. GDP, FDIIN, PS1, RQ and VA are turned out to be significant at $1 \%$, while $\mathrm{CC}$ is significant at $10 \%$ and coefficient on rule of law had $5 \%$ level of significance.

Again we can infer that volumes of mergers (economic size of M\&A deals) are positively linked to the rate of economic growth, inflows quality of regulations and voice accountability. Political instability, corruption had harmful effects on size of M\&A deals among BRICS economies.

TABLE 2

NUMBER OF SALE MERGERS IN BRICS COUNTRIES: PANEL DATA MODEL

\begin{tabular}{|c|c|c|c|c|}
\hline VARIABLES & $\begin{array}{l}1) \\
\text { Model FE1 }\end{array}$ & $\begin{array}{l}(2) \\
\text { Model RE1 }\end{array}$ & $\begin{array}{l}(3) \\
\text { Model FE2 }\end{array}$ & $\begin{array}{l}4) \\
\text { Model RE2 }\end{array}$ \\
\hline GDP & $\begin{array}{l}3.973 \\
(3.117)\end{array}$ & $\begin{array}{l}3.308 \\
(3.203)\end{array}$ & $\begin{array}{l}2.526 \\
(3.155)\end{array}$ & $\begin{array}{l}9.741 * * \\
(3.933)\end{array}$ \\
\hline Inflation & $\begin{array}{l}3.727 \\
(2.830)\end{array}$ & $\begin{array}{l}3.331 \\
(2.909)\end{array}$ & $\begin{array}{l}2.275 \\
(2.868)\end{array}$ & $\begin{array}{l}-4.809 \\
(3.518)\end{array}$ \\
\hline FDIIN & $\begin{array}{l}0.00178^{* * *} \\
(0.000184)\end{array}$ & $\begin{array}{l}0.00189 * * * \\
(0.000187)\end{array}$ & $\begin{array}{l}0.00176^{* * *} \\
(0.000203)\end{array}$ & $\begin{array}{l}0.00307 * * * \\
(0.000174)\end{array}$ \\
\hline FDIOUT & $\begin{array}{l}-1.24 \mathrm{e}-05 \\
(3.15 \mathrm{e}-05)\end{array}$ & $\begin{array}{l}-1.14 \mathrm{e}-05 \\
(3.27 \mathrm{e}-05)\end{array}$ & $\begin{array}{l}-1.09 \mathrm{e}-05 \\
(3.08 \mathrm{e}-05)\end{array}$ & $\begin{array}{l}1.82 \mathrm{e}-05 \\
(4.35 \mathrm{e}-05)\end{array}$ \\
\hline GE & & & $\begin{array}{l}-5.319^{*} \\
(2.819)\end{array}$ & $\begin{array}{l}0.404 \\
(2.192)\end{array}$ \\
\hline $\mathrm{CC}$ & & & $\begin{array}{l}-0.933 \\
(2.084)\end{array}$ & $\begin{array}{l}-4.088^{*} \\
(2.158)\end{array}$ \\
\hline PS1 & & & $\begin{array}{l}0.126 \\
(1.248)\end{array}$ & $\begin{array}{l}-4.947 * * * \\
(1.244)\end{array}$ \\
\hline RL & & & $\begin{array}{l}-2.188 \\
(2.589)\end{array}$ & $\begin{array}{l}3.156 \\
(3.117)\end{array}$ \\
\hline RQ & & & $\begin{array}{l}5.971 * * * \\
(2.224)\end{array}$ & $\begin{array}{l}5.551^{* *} \\
(2.535)\end{array}$ \\
\hline VA & & & $\begin{array}{l}-3.419 \\
(2.208)\end{array}$ & $\begin{array}{l}4.975 * * * \\
(0.853)\end{array}$ \\
\hline Constant & $\begin{array}{l}77.97 * * * \\
(22.87)\end{array}$ & $\begin{array}{l}75.31 \\
(60.07)\end{array}$ & $\begin{array}{l}425.2 * * \\
(168.7)\end{array}$ & $\begin{array}{l}-345.7 * * * \\
(73.62)\end{array}$ \\
\hline Observations & 112 & 112 & 111 & 111 \\
\hline R-squared & 0.486 & & 0.498 & \\
\hline Number of ID & 7 & 7 & 7 & 7 \\
\hline
\end{tabular}


We estimate above four panel data models for G7 economies and results on estimation of coefficients are presented in Table 3. These four models were estimated first taking the number of mergers as dependent variable and economic and institutional governance variables as independent variables and results are as presented in Table 4

For number of merger in Table 3, Model 1, FE1 coefficients of FDIIN, and constant are positive and significant at $1 \%$ level and that on corporate tax is negative and significant at $1 \%$ level while GDP is significant at $10 \%$. The equation has R-square value of 0.33 . Both FDIIN and FDIOUT contribute positively and significantly at $1 \%$ level under the random effect model RE1.

While FDIIN and GDP growth raise the number of M\&A deals, the higher rate of corporate tax and voice accountability reduce the number of such deals according to the estimated coefficients for Model 3 , FE2, where RQ variable is significant at $10 \%$. This equation has R-square value of 0.426 . Again more explanatory variables become significant when we augment the random effect model with institutional variables. Coefficients on FDIIN, FDIOUT, RQ and RL are positive and significant either at 1 or 5 percent level of significance. Political instability and voice accountability factors reduce the number of M\&A deals in this RE2 model in column (4) of Table 3.

TABLE 3

NUMBER OF MERGERS IN G7 COUNTRIES: PANEL DATA MODEL

\begin{tabular}{|c|c|c|c|c|}
\hline VARIABLES & $\begin{array}{l}(1) \\
\text { Model FE1 }\end{array}$ & $\begin{array}{l}(2) \\
\text { Model RE1 }\end{array}$ & $\begin{array}{l}(3) \\
\text { Model FE2 }\end{array}$ & $\begin{array}{l}(4) \\
\text { Model RE2 }\end{array}$ \\
\hline FDIIN & $\begin{array}{l}0.0103 * * * \\
(0.00148)\end{array}$ & $\begin{array}{l}0.0302 * * * \\
(0.00241)\end{array}$ & $\begin{array}{l}0.00883 * * * \\
(0.00151)\end{array}$ & $\begin{array}{l}0.0251 * * * \\
(0.00226)\end{array}$ \\
\hline FDIOUT & $\begin{array}{l}-0.00118 \\
(0.00110)\end{array}$ & $\begin{array}{l}0.00762 * * * \\
(0.00228)\end{array}$ & $\begin{array}{l}-0.000864 \\
(0.00107)\end{array}$ & $\begin{array}{l}0.00444 * * \\
(0.00206)\end{array}$ \\
\hline GDPgr & $\begin{array}{l}75.66^{*} \\
(42.51)\end{array}$ & $\begin{array}{l}82.30 \\
(90.70)\end{array}$ & $\begin{array}{l}89.79 * * \\
(41.40)\end{array}$ & $\begin{array}{l}96.95 \\
(83.81)\end{array}$ \\
\hline Inflation & $\begin{array}{l}92.84 \\
(89.53)\end{array}$ & $\begin{array}{l}107.8 \\
(167.3)\end{array}$ & $\begin{array}{l}30.66 \\
(90.84)\end{array}$ & $\begin{array}{l}172.3 \\
(162.6)\end{array}$ \\
\hline Ctax & $\begin{array}{l}-62.15^{* * * *} \\
(15.85)\end{array}$ & $\begin{array}{l}7.428 \\
(28.47)\end{array}$ & $\begin{array}{l}-45.24 * * \\
(17.67)\end{array}$ & $\begin{array}{l}33.24 \\
(30.78)\end{array}$ \\
\hline VA & & & $\begin{array}{l}-144.3^{* * *} \\
(32.53)\end{array}$ & $\begin{array}{l}-223.9^{* * *} \\
(37.47)\end{array}$ \\
\hline PS & & & $\begin{array}{l}-4.014 \\
(10.84)\end{array}$ & $\begin{array}{l}-50.07 * * * \\
(12.38)\end{array}$ \\
\hline GE & & & $\begin{array}{l}-6.978 \\
(38.30)\end{array}$ & $\begin{array}{l}14.84 \\
(71.03)\end{array}$ \\
\hline RQ & & & $\begin{array}{l}62.29^{*} \\
(34.01)\end{array}$ & $\begin{array}{l}136.7^{* *} \\
(53.49)\end{array}$ \\
\hline RL & & & $\begin{array}{l}-40.51 \\
(52.98)\end{array}$ & $\begin{array}{l}166.9 * * \\
(81.13)\end{array}$ \\
\hline $\mathrm{CC}$ & & & $\begin{array}{l}32.43 \\
(35.78)\end{array}$ & $\begin{array}{l}-99.64 \\
(64.22)\end{array}$ \\
\hline Constant & $\begin{array}{l}4,996 * * * \\
(535.7)\end{array}$ & $\begin{array}{l}578.4 \\
(989.4)\end{array}$ & $\begin{array}{l}13,362 * * * \\
(4,053)\end{array}$ & $\begin{array}{l}3,970 \\
(3,506)\end{array}$ \\
\hline Observations & 147 & 147 & 147 & 147 \\
\hline R-squared & 0.333 & & 0.426 & \\
\hline Number of ID & 7 & 7 & 7 & 7 \\
\hline
\end{tabular}

14 Journal of Applied Business and Economics Vol. 23(7) 2021 
Table 4 presents estimated results for G7 countries taking the value of merger deals as a dependent variable and all other economic and institutional and governance variables as independent variables. Fixed effect model (FE1) in column (1) reveals that FDIIN, GDP growth and constant contribute positively and significantly either at $1 \%$ or $5 \%$ levels of significance. This equation has an R-square value of 0.398 . Estimated coefficients of FDIIN and FDIOUT only are significant at 1\% level of significant in RE1 in column (2).Now we add institutional variables to these fixed and random effect models. The estimation of FE results in column (3) shows FDIIN and VA are significant in determining the volume of M\&A deals in these $\mathrm{G} 7$ countries with R-square at 0.436 .

As in the case of BRIC economies augmenting basic panel data model with institution variables makes this model more appealing as more variables turn out to be statistically significant. Coefficients on FDIIN FDIOUT and RQ are positive and significant either at 1 or 5 percent levels of significance and VA, PS and GE have negative and significant coefficients.

TABLE 4

VALUE OF MERGERS DEALS IN G7 COUNTRIES: PANEL DATA MODEL

\begin{tabular}{|c|c|c|c|c|}
\hline VARIABLES & $\begin{array}{l}(1) \\
\text { Model FE1 }\end{array}$ & $\begin{array}{l}(2) \\
\text { Model RE1 }\end{array}$ & $\begin{array}{l}(3) \\
\text { Model FE2 }\end{array}$ & $\begin{array}{l}\text { (4) } \\
\text { Model RE2 }\end{array}$ \\
\hline FDIIN & $\begin{array}{l}0.00254 * * * \\
(0.000297)\end{array}$ & $\begin{array}{l}0.00446 * * * \\
(0.000286)\end{array}$ & $\begin{array}{l}0.00227 * * * \\
(0.000316)\end{array}$ & $\begin{array}{l}0.00395 * * * \\
(0.000292)\end{array}$ \\
\hline FDIOUT & $\begin{array}{l}0.000102 \\
(0.000221)\end{array}$ & $\begin{array}{l}0.000851 * * * \\
(0.000273)\end{array}$ & $\begin{array}{l}0.000122 \\
(0.000223)\end{array}$ & $\begin{array}{l}0.000609 * * \\
(0.000266)\end{array}$ \\
\hline GDPgr & $\begin{array}{l}17.20 * * \\
(8.507)\end{array}$ & $\begin{array}{l}12.20 \\
(10.85)\end{array}$ & $\begin{array}{l}19.25^{* *} \\
(8.642)\end{array}$ & $\begin{array}{l}19.37^{*} \\
(10.83)\end{array}$ \\
\hline Inflation & $\begin{array}{l}5.385 \\
(17.92)\end{array}$ & $\begin{array}{l}13.43 \\
(19.93)\end{array}$ & $\begin{array}{l}-4.405 \\
(18.96)\end{array}$ & $\begin{array}{l}18.57 \\
(21.02)\end{array}$ \\
\hline Ctax & $\begin{array}{l}-3.795 \\
(3.172)\end{array}$ & $\begin{array}{l}3.310 \\
(3.382)\end{array}$ & $\begin{array}{l}-2.500 \\
(3.688)\end{array}$ & $\begin{array}{l}4.593 \\
(3.979)\end{array}$ \\
\hline VA & & & $\begin{array}{l}-16.81 * * \\
(6.790)\end{array}$ & $\begin{array}{l}-22.32 * * * \\
(4.843)\end{array}$ \\
\hline PS & & & $\begin{array}{l}2.428 \\
(2.262)\end{array}$ & $\begin{array}{l}-4.315^{* * * *} \\
(1.600)\end{array}$ \\
\hline GE & & & $\begin{array}{l}-2.897 \\
(7.995)\end{array}$ & $\begin{array}{l}-4.082 \\
(9.182)\end{array}$ \\
\hline RQ & & & $\begin{array}{l}7.641 \\
(7.100)\end{array}$ & $\begin{array}{l}13.77^{* *} \\
(6.915)\end{array}$ \\
\hline RL & & & $\begin{array}{l}-7.570 \\
(11.06)\end{array}$ & $\begin{array}{l}14.81 \\
(10.49)\end{array}$ \\
\hline $\mathrm{CC}$ & & & $\begin{array}{l}7.163 \\
(7.469)\end{array}$ & $\begin{array}{l}-7.207 \\
(8.302)\end{array}$ \\
\hline Constant & $\begin{array}{l}264.4 * * \\
(107.2)\end{array}$ & $\begin{array}{l}-167.4 \\
(117.6)\end{array}$ & $\begin{array}{l}1,175 \\
(846.0)\end{array}$ & $\begin{array}{l}556.0 \\
(453.3)\end{array}$ \\
\hline Observations & 147 & 147 & 147 & 147 \\
\hline R-squared & 0.398 & & 0.436 & \\
\hline Number of ID & 7 & 7 & 7 & 7 \\
\hline
\end{tabular}

Now we estimate those four models in case of G20 economies. Table 5 depicts the estimated results of four panel data models for G20 countries. First number of mergers is taken as dependent variable and 
economic and institutional governance variables are taken as independent variables in Table 5. Coefficients on FDIIN and constant and FDIOUT are significant positive determinants of numbers of M\&A deals at 1\% and 5\% respectively in panel fixed effect (FE1) model in column (1). Higher rate of corporation tax reduces the number of M\&A deals in G20 countries. This is significant at 1\% level of significance. The R-square value of the estimated equation stands at 0.319 . Then in the random effect panel model (RE1) in column (2) only coefficients on FDIIN, constant and FDIOUT are positive and significant at $1 \%$ level of significance. Corporation tax reduces the number of M\&A deals significantly.

In Model 3 FE2 in column (3) of Table 5, FDIIN, VA and constant play positive roleand are significant at $1 \%$, FDIOUT is positive and significant at 5\%. Institutional factors such as the rule of law (RL) and government effectiveness raise number of M\&A deals in G20 countries but the VA is a negative factor for such deals. The R-square value of this equation is 0.353 . In the random effect panel data model (RE2) in column (4) positive and highly significant factors for M\&A deals include FDIIN, FDIOUT, GE and RL, with $1 \%$ level of significance. Higher the corporate tax, lower the M\&A deals significantly.

TABLE 5

NUMBER OF MERGERS IN G20 COUNTRIES: PANEL DATA MODEL

\begin{tabular}{|c|c|c|c|c|}
\hline VARIABLES & $\begin{array}{l}\text { (1) } \\
\text { Model FE1 }\end{array}$ & $\begin{array}{l}(2) \\
\text { Model RE1 }\end{array}$ & $\begin{array}{l}\text { (3) } \\
\text { Model FE2 }\end{array}$ & $\begin{array}{l}\text { (4) } \\
\text { Model RE2 }\end{array}$ \\
\hline FDIIN & $\begin{array}{l}0.0106 * * * \\
(0.00110)\end{array}$ & $\begin{array}{l}0.0162 * * * \\
(0.00135)\end{array}$ & $\begin{array}{l}0.0101 * * * \\
(0.00110)\end{array}$ & $\begin{array}{l}0.0149 * * * \\
(0.00128)\end{array}$ \\
\hline FDIOUT & $\begin{array}{l}0.00201 * * \\
(0.000833)\end{array}$ & $\begin{array}{l}0.00501 * * * \\
(0.00106)\end{array}$ & $\begin{array}{l}0.00171 * * \\
(0.000826)\end{array}$ & $\begin{array}{l}0.00348 * * * \\
(0.00100)\end{array}$ \\
\hline GDPgr & $\begin{array}{l}-4.874 \\
(13.49)\end{array}$ & $\begin{array}{l}-17.58 \\
(16.96)\end{array}$ & $\begin{array}{l}3.374 \\
(13.63)\end{array}$ & $\begin{array}{l}-4.305 \\
(16.14)\end{array}$ \\
\hline Inflation & $\begin{array}{l}5.506 \\
(7.278)\end{array}$ & $\begin{array}{l}-10.96 \\
(8.870)\end{array}$ & $\begin{array}{l}11.10 \\
(7.411)\end{array}$ & $\begin{array}{l}3.890 \\
(8.707)\end{array}$ \\
\hline Ctax & $\begin{array}{l}-64.35 * * * \\
(10.10)\end{array}$ & $\begin{array}{l}-28.01 * * \\
(11.62)\end{array}$ & $\begin{array}{l}-54.62 * * * \\
(10.47)\end{array}$ & $\begin{array}{l}-27.55^{* *} \\
(12.00)\end{array}$ \\
\hline VA & & & $\begin{array}{l}-35.52 * * * \\
(12.77)\end{array}$ & $\begin{array}{l}-10.44 \\
(7.609)\end{array}$ \\
\hline PS & & & $\begin{array}{l}-4.867 \\
(5.018)\end{array}$ & $\begin{array}{l}-8.098 \\
(5.535)\end{array}$ \\
\hline GE & & & $\begin{array}{l}17.71^{*} \\
(10.30)\end{array}$ & $\begin{array}{l}35.75 * * * \\
(11.73)\end{array}$ \\
\hline RQ & & & $\begin{array}{l}3.141 \\
(8.895)\end{array}$ & $\begin{array}{l}2.211 \\
(9.828)\end{array}$ \\
\hline RL & & & $\begin{array}{l}29.46 * * \\
(12.07)\end{array}$ & $\begin{array}{l}31.23 * * * \\
(11.78)\end{array}$ \\
\hline $\mathrm{CC}$ & & & $\begin{array}{l}-4.464 \\
(8.797)\end{array}$ & $\begin{array}{l}-13.81 \\
(9.616)\end{array}$ \\
\hline Constant & $\begin{array}{l}3,436 * * * \\
(309.7)\end{array}$ & $\begin{array}{l}2,080 * * * \\
(383.2)\end{array}$ & $\begin{array}{l}2,519 * * * \\
(931.3)\end{array}$ & $\begin{array}{l}-731.8 \\
(624.3)\end{array}$ \\
\hline Observations & 400 & 400 & 398 & 398 \\
\hline $\begin{array}{l}\text { R-squared } \\
\text { Number of ID }\end{array}$ & $\begin{array}{l}0.319 \\
20\end{array}$ & 20 & $\begin{array}{l}0.353 \\
20\end{array}$ & 20 \\
\hline
\end{tabular}

Standard errors in parentheses*** $\mathrm{p}<0.01,{ }^{* *} \mathrm{p}<0.05,{ }^{*} \mathrm{p}<0.1$ 
Table 6 provides the estimated coefficients of corresponding four versions of panel regression models for G20 countries, taking the value of mergers as the dependent variable and economic and institutional governance factors as independent variables.

Model 1 FE1, reveals that value of merger deals depends very significantly on FDIIN, FDIOUT, and constant factors. Corporate tax reduces it significantly. The equation has an R-square value of 0.389 .

Only coefficients of FDIIN and FDIOUT are at $1 \%$ level of significance in determining the value of deals in G20 economies in the random effect model (RE1)

Model 3 FE2 reveals that FDIIN FDIOUT and corruption control (CC) are significant and positive factors determining the value of M\&A deals. Corporate tax and VA turned out to have negative and significant factors for the size of deals at $5 \%$ level of significance. R-square value of this model stands at 0.405. Only FDIIN and FDIOUT were significant for explaining the value of M\&A deals in the random effect panel data model (RE2) in column (4).

These results indicate that the better institutions promote the number of M\&A deals but do not have significant influence if the size of the mergers.

TABLE 6

VALUE OF MERGERS DEALS IN G20 COUNTRIES: PANEL DATA MODEL

\begin{tabular}{|c|c|c|c|c|}
\hline VARIABLES & $\begin{array}{l}(1) \\
\text { Model FE1 } \\
\end{array}$ & $\begin{array}{l}(2) \\
\text { Model RE1 } \\
\end{array}$ & $\begin{array}{l}(3) \\
\text { Model FE2 } \\
\end{array}$ & $\begin{array}{l}(4) \\
\text { Model RE2 }\end{array}$ \\
\hline FDIIN & $\begin{array}{l}0.00252 * * * \\
(0.000186)\end{array}$ & $\begin{array}{l}0.00311 * * * \\
(0.000188)\end{array}$ & $\begin{array}{l}0.00246 * * * \\
(0.000189)\end{array}$ & $\begin{array}{l}0.00292 * * * \\
(0.000187)\end{array}$ \\
\hline FDIOUT & $\begin{array}{l}0.000306^{* *} \\
(0.000141)\end{array}$ & $\begin{array}{l}0.000617^{* * *} \\
(0.000149)\end{array}$ & $\begin{array}{l}0.000285^{* *} \\
(0.000142)\end{array}$ & $\begin{array}{l}0.000444 * * * \\
(0.000148)\end{array}$ \\
\hline GDPgr & $\begin{array}{l}2.582 \\
(2.281)\end{array}$ & $\begin{array}{l}0.464 \\
(2.386)\end{array}$ & $\begin{array}{l}3.225 \\
(2.339)\end{array}$ & $\begin{array}{l}1.895 \\
(2.376)\end{array}$ \\
\hline Inflation & $\begin{array}{l}0.951 \\
(1.231)\end{array}$ & $\begin{array}{l}-0.333 \\
(1.237)\end{array}$ & $\begin{array}{l}1.581 \\
(1.272)\end{array}$ & $\begin{array}{l}0.969 \\
(1.280)\end{array}$ \\
\hline Ctax & $\begin{array}{l}-4.291 * * \\
(1.709)\end{array}$ & $\begin{array}{l}-0.904 \\
(1.596)\end{array}$ & $\begin{array}{l}-4.106 * * \\
(1.797)\end{array}$ & $\begin{array}{l}-1.933 \\
(1.760)\end{array}$ \\
\hline VA & & & $\begin{array}{l}-4.487 * * \\
(2.192)\end{array}$ & $\begin{array}{l}-0.596 \\
(1.095)\end{array}$ \\
\hline PS & & & $\begin{array}{l}0.438 \\
(0.861)\end{array}$ & $\begin{array}{l}-0.258 \\
(0.810)\end{array}$ \\
\hline GE & & & $\begin{array}{l}1.297 \\
(1.768)\end{array}$ & $\begin{array}{l}2.538 \\
(1.722)\end{array}$ \\
\hline RQ & & & $\begin{array}{l}-0.788 \\
(1.527)\end{array}$ & $\begin{array}{l}-0.520 \\
(1.439)\end{array}$ \\
\hline RL & & & $\begin{array}{l}0.364 \\
(2.072)\end{array}$ & $\begin{array}{l}0.532 \\
(1.718)\end{array}$ \\
\hline $\mathrm{CC}$ & & & $\begin{array}{l}2.532^{*} \\
(1.510)\end{array}$ & $\begin{array}{l}1.351 \\
(1.411)\end{array}$ \\
\hline Constant & $\begin{array}{l}170.3 * * * \\
(52.39)\end{array}$ & $\begin{array}{l}41.45 \\
(51.95)\end{array}$ & $\begin{array}{l}204.2 \\
(159.8)\end{array}$ & $\begin{array}{l}-141.1 \\
(90.65)\end{array}$ \\
\hline Observations & 400 & 400 & 398 & 398 \\
\hline R-squared & 0.389 & & 0.405 & \\
\hline Number of ID & 20 & 20 & 20 & 20 \\
\hline
\end{tabular}

Standard errors in parentheses, ${ }^{* * *} \mathrm{p}<0.01,{ }^{* *} \mathrm{p}<0.05,{ }^{*} \mathrm{p}<0.1$ 
Final issue we like to investigate is how the heterogeneity among these G20 economies comes into play in determining the value of M\&A deals in them. We expect these M\&A deals to be influenced by the levels of development of the economy. We estimate a quantile regression model to find answers to this question. As above despite heterogeneity, coefficients on FDIIN and FDIOUT are significant at $1 \%$ level of significance in quantile regression model 1 in column (1) in Table 7. It was surprising to have lower impact of GDP growth in the value of M\&A deals in this model. Results for the robust quintile panel data model are given in column (2) of Table 7 where FDIIN, FDIOUT and Inflation has positive and highly significant influence in the value of M\&A deals in G20 economies. GDP growth lowers the value of M\&A deals in this model too.

TABLE 7

VALUE OF MERGERS DEALS IN G20 COUNTRIES: PANEL QUANTILE REGRESSION

\begin{tabular}{|c|c|c|}
\hline VARIABLES & $\begin{array}{l}\text { (1) } \\
\text { Model quantile1 }\end{array}$ & $\begin{array}{l}\text { (2) } \\
\text { Robust quantile2 }\end{array}$ \\
\hline FDIIN & $\begin{array}{l}0.00220 * * * \\
(3.54 \mathrm{e}-05)\end{array}$ & $\begin{array}{l}0.00230 * * * \\
(2.43 \mathrm{e}-05)\end{array}$ \\
\hline FDIOUT & $\begin{array}{l}0.00194 * * * \\
(4.56 \mathrm{e}-05)\end{array}$ & $\begin{array}{l}0.00182 * * * \\
(1.42 \mathrm{e}-05)\end{array}$ \\
\hline GDPgr & $\begin{array}{l}-0.332 * * * \\
(0.115)\end{array}$ & $\begin{array}{l}-0.459 * * * \\
(0.139)\end{array}$ \\
\hline Inflation & $\begin{array}{l}-0.0249 \\
(0.0997)\end{array}$ & $\begin{array}{l}0.299 * * * \\
(0.0535)\end{array}$ \\
\hline $\begin{array}{l}\text { Observations } \\
\text { Number of groups }\end{array}$ & $\begin{array}{l}400 \\
20\end{array}$ & $\begin{array}{l}400 \\
20\end{array}$ \\
\hline
\end{tabular}

Table 7 represents two models for the G20 quantile panel regressions using the value of mergers as dependent variable.

Overall, we have found the FDIIN and FDIOUT and the level of GDP and institutional factors play highly significant roles in determining either the number or the value of the M\&A deals among firms in BRICS, G7 and G20 countries with slight differences in magnitudes of these results. Further investigation with firm level data is required to see the influence of sectoral, regional or corporate structure factors. This is an issue open for further research.

\section{CONCLUSIONS}

Factors contributing toward increasing numbers of M\&A deals among firms and volume of business and sales of these firms are assessed empirically in this investigation. Major findings of this study are that while the economic growth and FDI contribute positively to the occurrence of M\&A activities, these effects are even more prominent with efficiency in government institution, qualities of regulation, voice accountability and control of corruption. In the meantime, higher inflation and corporation tax reduce the M\&A activities. Medium or large corporations merge to exploit scale economies, to benefit from larger markets and to retain market power by operating across the globe. These results are based on results of the static and dynamic panel data models for BRICS, G7 and G20 countries. 


\section{REFERENCES}

Andrade, G., Mitchell, M., \& Stafford, E. (2001). New evidence and perspectives on mergers. Journal of Economic Perspectives, 15(2), 103-120.

Appadu, N., Faelten, A., Moeller, S., \& Vitkova, V. (2012). Assessing market attractiveness for mergers and acquisitions: The MARC M\&A maturity index. Cass Business School, City University London.

Beitel, P., Schiereck, D., \& Wahrenburg, M. (2004). Explaining M\&A success in European banks. European Financial Management, 10, 109-139.

Boateng, A., Hua, X., Uddin, M., \& Du, M. (2014). Home country macroeconomic factors on outward cross-border mergers and acquisitions: Evidence from UK. Research in International Business and Finance, 30, 202-216.

Carril-Caccia, F., \& Pavlova, E. (2020). Mergers and acquisitions \& trade: A global value chain analysis. The World Economy, 43(3), 586-614.

Cirjevskis, A. (2015). Empirical Testing of Arctic Model for Assessment of Competence Based Synergy in Acquisition Process. Journal of Business Management, (9).

DePamphilis, D. (2003). Acquisitions and Other Restructuring Activities: An Integrated Approach to Process, Tools, Cases, and Solutions. Butterworth-Heinemann.

di Giovanni, J. (2005). What drives capital flows? The case of cross-border M\&A activity and financial deepening. Journal of International Economics, 65, 127-149.

Dunning, J.H. (1980). Toward an Eclectic Theory of International Production: Some Empirical tests. Journal of International Business Studies, 11, 9-31.

Eaton, G.W., Liu, T., \& Officer, M.S. (2019). Rethinking Measures of Mergers \& Acquisitions Deal Premiums. Journal of Financial and Quantitative Analysis, pp. 1-30.

Epstein, M.J. (2005). The Determinants and Evaluation of Merger Success. Business Horizon, 48, 37-46.

Farrell, J., \& Shapiro, C. (1990). Horizontal Mergers: An Equilibrium Analysis. The American Economic Review, 80(1), 107-126.

Floyd, D. (2003). FDI Through Cross-Border Acquisition and Greenfield Investment in Poland. Journal of East-West Business, 9(3-4), 53-72.

Ghosh, S. (2008). Leverage foreign borrowing and corporate performance: Firm-level evidence for India. Applied Economics Letters, 15, 607-616.

Golbe, D.L., \& White, L.J. (1988). A Time-Series Analysis of Mergers and Acquisitions in the US Economy. Corporate Takeovers: Causes and Consequences, University of Chicago Press.

Harford, J. (2005). What drives merger waves? Journal of Financial Economics, 77(3), 529-560.

Hazelkorn, T., Zenner, M., \& Shivdasani, A. (2004). Creating value with mergers and acquisitions. Journal of Applied Corporate Finance, 16(2-3), 81-90.

Hirshleifer, D. (1995). Mergers and Acquisitions: Strategic and Informational Issues. Chapter 26 of R.A. Jarrow, V. Maksimovic, \& W.T. Ziemba (Eds.). Finance.

Jayanthi, B., Sivakumar, S.N.V., \& Haldar, A. (2016). Cross-border Acquisitions and Host Country Determinants: Evidence From Indian Pharmaceutical Companies. Sage Publishers, 17(3), 68499.

Jensen, M. (1986). Agency Costs of Free Cash Flow, Corporate Finance, and Takeovers. The American Economic Review, 76(2), 323-329.

Kavanagh, M.H., \& Ashkanasy, N.M. (2006). The Impact of Leadership and Change Management Strategy on Organizational Culture and Individual Acceptance of Change during a Merger. British Journal of Management, 17(S1), S81-S103.

Kim, D.H. (2010). Making or breaking a deal: The impact of electoral systems on mergers \& acquisitions. Kyklos, 63(3), 432-449.

King, D., Dalton, D.R., Daily, C.M., \& Covin, J.G. (2004). Meta-analyses of Post-Acquisition Performance: Indications of Unidentified Moderators. Strategic Management Journal, 22, 187200 
Kyriazis, D. (2010). The long-term post acquisition performance of Greek acquiring firms. International Research Journal of Finance and Economics, 43(1), 69-79.

Leepsa, N.M., \& Mishra, C.S., (2013). Do mergers \& Acquisitions pay off immediately? Evidence from mergers \& Acquisitions in India. South Asian Journal of Management, 20(3), 39-57.

Leibenstein, H. (1966). Allocative Efficiency vs. "X-Efficiency”. The American Economic Review, 56(3), 392415.

Martynova, M., Oosting, S., \& Renneboog, L. ( 2007). The long-term operating performance in European mergers and acquisitions. In International mergers and acquisitions activity since 1990 (pp. 79116). Academic Press.

Mitchell, M.L., \& Mulherin, J.H. (1996). The Impact of Industry Shocks on Takeover and Restructuring Activity. Journal of Financial Economics, 41, 193-229.

Nigh, J.O., \& Boschetti, M. (2006). M\&A due diligence: The 360-degree view. Retrieved from https://imaa-institute.org/category/publications/page/47/

Orefice, G., Sly, N., \& Toubal, F. (2021). Cross-Border Merger and Acquisition Activity and Wage Dynamics. ILR Review, 74(1), 131-162.

Ouyang, W., \& Hilsenrath, P. (2017). Merger \& Acquisition and Capital Expenditure in Health Care: Information Gleaned From Stock Price Variation. Inquiry, 54, 1-7.

Roll, R. (1986). The Hubris Hypothesis of Corporate Takeovers. Journal of Business, 59, 197-216.

Sehgal, S., Delistingee, S., \& Deisting, F. (2012). The impact of M\&A announcement and financing strategy on stock returns: Evidence from BRICKS markets. International Journal of Economics and Finance, 4, 76-90.

Shleifer, A., \& Vishny, R.W. (2003). Stock market driven acquisitions. Journal of Financial Economics, 70(3), 295-311.

Tamosiuniene, R., \& Duksaite, E. (2011). Why Companies Decide to Participate in Mergers and Acquisition Transactions Business in XXI century.

Tirole, J., \& Jean, T. (1988). The theory of industrial organization. MIT press.

Travlos, N.G. (1987). Corporate takeover bids, methods of payment, and bidding firms' stock returns. Journal of Finance, 42, 943-963.

Vazirani, N. (2012). Mergers and Acquisitions performance evaluation: A literature review. SIES Journal of Management, 8(2), 37-52.

Weaver, S., Harris, R., Bielinski, D., \& MacKenzie, K. (1991). Merger and Acquisition Valuation. Financial Management, 20(2), 85-96.

Xia, J., Tan, J., \& Tan, D. (2008). Mimetic entry and bandwagon effect: The rise and decline of international equity joint venture in China. Strategic Management Journal, 29(2), 195217.

Retrieved from www.mergermarket.com, https://www.emis.com/php/dealwatch 